\title{
ANGUISH IN ALEXANDER DUMAS' NOVEL THE COUNT OF MONTE CRISTO
}

\author{
Hidayati ${ }^{1}$, Arifuddin ${ }^{2}$, Zainab $\mathrm{MZ}^{3}$, Aflina $^{4}$ \\ 1, 2, 3, ${ }^{4}$ Faculty of Language and Communication \\ Harapan University Medan \\ E-mail: yatihida853@gmail.com
}

Received: 02 December 2019

Accepted: 12 December 2019

\begin{abstract}
The research is conducted based on the novel The Count of Monte Cristo, written by a French writer Alexander Dumas. The focus goes to anguish experienced by the protagonist of the novel, Edmond Dante, a young and handsome sailor with a brilliant prospects in career making him plunged into life of anguish. He is arrested for no reason, sent to jail with inhuman treatment. Descriptive qualitative method is applied to reveal that literary works are mirrors of all the occurrences in society. This is in line with the sociology of literature also implemented here as the approach to further analysis of the subject matters having three aspects to be used as a literary research guidelines: social contexts of the author, already showed by the author, literature as the reflection of society, revealed through the text tending to social reality and functions of literature as entertainer or remodel of society, exposed through the responses of the readers. The results show that the novel contains anguish subdivided into Nonprocedural Arrest and Inhuman Imprisonment covering the whole study.
\end{abstract}

Keywords: anguish, Non-procedural arrest, Inhuman Imprisonment.

\section{Introduction}

The count of Monte Cristo is a novel written just before Napoleon's first exile to the island of Elba. Various political problems in France at that time are also illustrated through this novel. France, at the time this novel is written, is not a safe country, not only for the comers but also for the people of France. Various crimes are found. Everyone feels uncomfortable and always beset by fear because at any time they can be arrested by the authorities on unclear charges. Defamation is a practical tool for bringing down opponents. This happens to Edmond Dantes, the protagonist of the novel who is also arrested only because a prosecutor named Villefort feels uncomfortable at the visit of Edmond Dantes to Elba, delivering a letter from the former captain of the ship, who dies on the way home. Villfort is anxious to know that the addressee of the letter is his own father, the loyalist to Napoleon. If this is known, he will be in danger, so he has to do anything to dump Dantes.

All these chaotic situations do not only develop at the time of Napoleon's first fall. After Napoleon has been completely defeated, France is led by a series of monarchies and for quite a long time, political and economic conditions are also unstable. The changes of authorities do not necessarily provide security and comfort and welfare to the community. This transfer of power make things even more complicated because the new rulers are busy cleaning up all government bureaucracies, community organizations and ordinary people 
from Napoleon's influence and followers. Thousands of innocent people have fallen victim to this revolution.

This novel was written around 1844 by a French writer named Alexander Dumas and goes on to become a best seller novel, a master piece and has also been translated into various languages. This novel has various segments in its storyline and this is an author's expertise in organizing the entire segments into an interesting plot, filled with various thrills providing entertainment, teaching and also a deep impression for the readers. Through language modification and high imagination, the writer is able to unite historical elements into a fiction, then a historical novel is published.

In addition to playing with so many segments of the storyline, the writer is also able to present the key character in the novel, Napoleon, who has a very significant role in the progress of the plot; but the real role of Napoleon in the story is not seen. Napoleon becomes the inspiration or source of stories overshadowing the entire storyline so that Napoleon becomes one of the main characters in the novel. The entire story segment is centered on Napoleon or in other words all the events in the novel remain related to Napoleon.

Because of his loyalty, perseverance, and also his skills in manning a ship, Dantes is appointed by the ship company to be the captain, replacing the previous captain. But unfortunately, before he is legalized as captain, Dantes experiences a very painful calamity, a tragedy. Through a terrible conspiracy designed by four people: Fernand Mondego, Danglars, Caderousse and Villefort, Dantes is vilified as a follower of Napoleon and this is the beginning of the fall of Dantes. He cannot do anything; he is completely helpless because he is not given the opportunity to defend himself.

The motives behind this conspiracy vary. For Fernand Mondego, Dantes is a love barrier. Fernand loves a beautiful girl named Mercedes but his love is rejected by Mercedes because she prefers Dantes. Fernand feels jealous of Dantes and assumes that Dantes has snatched Mercedes from his hand. For Danglars, Dantes does not deserve to be the captain of the ship. Danglers thinks that he has full rights to be the captain and owing to this, he feels disappointed and wishes to have revenge on Dantes. Caderousse, the third conspirator, a man with no principle of life, has absolutely no motive for Dantes; he is a neighbor of Dantes who is willing to be a member of the plot only because he is easily influenced by his friends to antagonize Dantes. For Villefort, Dantes is not an enemy and he has got nothing to do with $\mathrm{He}$ is driven by extreme fear so he has to crush Dantes. The letter Dantes brings to the island of Elba is addressed to his father, a loyal follower of Napoleon and if anyone knows that he is the son of a follower of Napoleon, then his life is finished.

All those who stand aginst Dantes have lost their common sense. They do not think wisely consequently they act brutally. They have showed vices which might be inherited from their family or environment. They ignore the real sense of local wisdom, which is much useful for the guidelines of social life. Local wisdom is an idea or wisdom inherited from previous generations and used as a reference in living social life in harmony. (Hidayati: 2018) The existence of a person more or less is also influenced or determined by his previous generation. This means that if nothing good is thought to the next generation, the present generation is to be blamed.

There are two sub-subject matters of this study: Non-procedural Arrest and Inhuman Imprisonment, both are filled by great anguishes. Dantes is in a great depression, filled with anguish when he is arrested just when he is celebrating his wedding. The arrest takes so prompt that he has no chance to ask the reason of his being arrested. Following this Dantes 
again has encountered disappointment for being betrayed in the court trial. This is clearly a great blow for him. And without any information, he is sent to the most terrible prison in France, the Chateu d'if, where he has to spend his life for unknown time. The condition of the prison and the treatment he receives all make him almost lose his hope to live on. When he is out of the prison, again he has to swallow another bitter anguish as his girl, Mercedes is married to a man, who is also his enemy.

\section{Literature Review}

The approach used in this study is the sociology of literature. Sociology of literature is an approach that departs from orientation to the universe, but can also depart from orientation to authors and readers. According to the approach of sociology of literature, literary works are seen from their relationship with reality, the extent to which literary works reflect reality. The reality here is quite broad in meaning, that is, everything that is outside the literary work and which is referred to by the literary work itself.

The sociology of literature is a research focused on human problems because literature often reveals the struggle of humanity in determining the future, based on imagination, feelings, and intuition (Endraswara, 2003: 79). The approach of sociology of literature focuses on literary works as primary data to interpret the world view of the author, the spirit of the times, social conditions of society, or the process of social change of literary works as a manifestation of literature as social documents or literature as a mirror of society.

There are three aspects used in the approach, the first is the social context of the author. This refers to the author's social position in society and the relation to the reading community. Secondly, it is literature as a mirror of society, that is, literature reflects the society at the time the work is written, the extent to which the character of the author influences the image of the society to be conveyed, and the extent to which the literary genre used can represent all elements of society. Third, is the social function of literature, as a mere entertainer or as a remodel of society, and the extent of possible synthesis of the two. (Faruk: 2013)

Then to support the elaborations of suffering faced by the protagonist at the time of his arrest and during his imprisonment, the concepts of anguish or agony are presented here. Anguish and suffering are two sides of a coin, meaning that when a person talking of anguish, he is also talking of suffering. Suffering is a part of life, omnipresent in our life, and existing in all phases of life. It is present in many forms, some of which are more obvious than others. The most evident and recognizable suffering is the physical type of suffering which can be observed all around us.

\subsection{Anguish}

Almost everyone who lives on this planet will witness sadness, suffering or anguish at least once in a lifetime. Anguish is defined as a pain owing to injury, medical malpractice or even a disturbance in someone's family life and several other things. Even though people suffer misery, they continue to suffer. Life is full of anguish and no one could escape from this life line.

Human anguish is the pain one feels inside when something bad has happened to him or someone close to him. There are two types of anguish: one is caused by another person, and the other type is caused by nature (Gentil and Gentil: 2009). Anguish caused by others usually covers both criminal and civil crimes. If someone is injured, then the action is an anguish that falls into the category of criminal act and if someone is defamed or betrayed, 
then the action is included in the category of civil crime. But that does not mean that criminal offenses are more severe than civil crimes or vice versa, both equally produce painful anguish. There is even a saying stating that that slandering is more cruel than murdering.

Another type of anguish comes from nature and in this case there is no human being who is able to face the forces of nature. Storm or earthquake, for example, clearly gives anguish to humans and this power cannot be controlled by humans. In contrast to anguish made by humans, anguish derived from nature is a warning to humans that basically humans are weak creatures and such does not make people related to anger, offence or revenge. Humans can do nothing facing anguish from nature.

\subsection{Arrest Procedure}

When the police arrest someone, they also at the same time revoke his right for freedom while the right of freedom, in which there is a right to move freely is a fundamental right of every human being and this certainly refers to human rights. Therefore the police must attend to standard procedures in arresting someone. Everything must be prepared including a warrant and other important matters and documents for the reasons of the arrest.

The arrest procedure is certainly different in one place and another, adapted to the social and cultural context of the community and the environment. Sometimes the police provide additional arrest procedures with the aim of protecting their members from unwanted things. Even sometimes the arrest procedure can deviate from the standard procedures that have been set and everything of course depends on the situation on the ground. However, as long as the police can provide rational and accountable information, all forms of deviation from arrest procedures can be accepted. For example: the police may shoot dead a criminal at the time of arrest if they feel threatened and can become victims.

Arrests can only be made if the police feel absolutely certain that the person concerned is someone who has violated the law and deserves to be arrested because if not, it could endanger other parties. And this is certainly supported by observational actions, and supervision that have been done before; thus there is no error in arresting a person. Someone who is wrongly arrested can sue for his lost rights even though detention is carried out only in a short time, which means that someone must have the right to comfort and security wherever he is and this is certainly found in the constitution of every country. The state must be able to protect every citizen. (Eby: 2002)

\subsection{Against the Rights of a Prisoner}

When a person commits an act of crime, then according to law, that person must pay for all of his actions and there are two systems that are generally used in the redemption of a crime, through fines or detention. Thus the person will not repeat his actions again and this can be an example to the community that every crime has consequences. From this it can be seen that the purpose of imprisonment is for people to repent and not repeat their crimes, not as a place of torture because after all a prisoner is a human being and a human being is basically good. Criminals are good people who make mistakes, so the purpose of the law is to return the person to good condition again. Everyone has the right to be protected or in other words, everyone has the right to legal protection. This of course refers to the proper treatment that must be obtained by prisoners. 
Prison system is not a joke. It is time to make some changes in prison system to the many rights held by these prisoners. Cruel and unusual punishment must not be used and at the same time luxury is not supposed to be offered. A prisoner is also a human and as a human, the person concerned is to be protected and served well. Not all those who get into prisons are bad; some are trapped doing things they do not realize. And one thing to be made base of consideration is that man basically is good. (Coyle: 2002)

\section{Research Method}

Descriptive qualitative method is used in this study having mechanism of research design, data collection procedures and data analysis procedures. In qualitative research method, the data are taken from texts and are then explored and analyzed using descriptive qualitative method since it intends to identify clauses, sentence and will be interpreted into the form of words rather than numbers (Creswell, 2013: 88). By this the various forms of data taken from novel as the primary source, are oriented to types of anguish faced by the protagonist: Non-procedural Arrest and Inhuman Imprisonment.

Qualitative research is concerned with the opinions, experiences and feeling of individuals producing subjective data. It describes social phenomena as they occur naturally. No attempt is made to manipulate the situation under the study as is the case with experimental qualitative research. Data are used to develop concepts and theories that help us to understand to social world. This is an approach to development of theory. Qualitative research is deductive in that it tests which have already been proposed.

Similarly, Herbert (2010: 54)) states that in the process of interpreting the data, it can be collected and interpreted specifically and contextually. Thus, this study uses descriptive qualitative method in interpreting the data since it mainly focuses on identifying the types of anguish in the novel.

This research shows the nature of the situation as it exists at the time of the study. That is why this research uses descriptive design. The data of this study belong to the nonmanipulated variables as they are not the result of experiment.

\section{Results and Discussion}

The protagonist of the novel The Count of Monte Cristo by Alexander Dumas, leads a life of anguish. This starts from the time when he gets married till he escapes from the terrible prison Chateu d'if. He has been betrayed by his friends as they are jealous of him owing his career and his fate to get married with a beautiful girl, Mercedes. He has been accused of having sided the Bonapartist Party. He is always faced by one after another anguish, an extreme and prolonged pain.

\subsection{Non-procedural Arrest}

Dantes is pictured experiencing various problems, all of which are a unification of anguish. The Anguish he experiences starts from his wedding. He is helpless at all to face all the problems imposed on him. Evern he is unable to do his praying well. Dantes tries to convince the magistrates that he is not involved in any form of crime as at that moment of his arrest he says that he is at the festival of his marriage. Dantes realizes the contrast between the happy moment and the painful situation he is now undergoing. (Dumas, 2000: 56)

From one side, Dantes is indeed a lucky man because he can marry a Mercedes, a very beautiful French girl and all men must be jealous of this good fortune. Mercedes also knows 
that he marries the right person, because besides being handsome, Dantes also has good character, and intelligence. For Mercedes Dantes is a perfect man and of course Mercedes also feels fortunate to be able to walk together with Dantes.

But behind this luck, there is a dark shadow keeping on following the life of Dantes; black shadow which then destroys his life. Everything starts from here. Dantes feels very sad when he is forcefully separated from his wife. He rebels and does not not want to be arrested, because he knows that he does not break the law and none of his actions could get him arrested by the authorities. Another thing that is very painful is that the authorities do not tell him the reason for his arrest. They also do not show an official warrant which means that the arrest is illegal. Physical clashes with security forces make Dantes finally surrender and follow their wishes. The magistrate says that he has arrested Dantes in the name of law and he continues that he cannot inform Dantes but Dantes will be duly acquainted with the reasons that have rendered such a step necessary at his first examination. (Dumas, 2000: 45)

From what is illustrated here, Dantes clearly experiences an injustice, tending to extreme anugish. The arrests made against him does not follow the standard of arrest procedures. They should have informed Dantes of his actions resulted in his arrest. They should also have told him that he could defend himself through a lawyer, either appointed by the state or himself. All of this certainly adds to his anguish. He is desperate, really does not know what to do or to whom he has to tell his fate. All roads seem closed to him.

Dantes begins to think that his life would end. He keeps on thinking about the fate of his wife who subsequently has no direction because he could not be together again with his wife. Only in that very brief time, Dantes has experienced a dark depression. The thought of death always crosses over his mind. All arrest procedures are ignored by the security forces. In fact they also do not tell where they would take Dantes. (Duman, 2000: 56)

This angish is actually not only felt by Dantes. Mercedes, his wife, also feels shocked. He also love Dantes and now his beloved person is forced to leave her. Mercedes, like Dantes, also does not know what to do. Mercedes is stunned sadly remembering her tragic fate. She gets surprised to think of the fate of a Dantes, who so far she knows is a good young man who does not have a record of crime to be arrested by the authorities. Mercedes and Dantes realize that they are too small to face the authorities. As a wife, Mercedes, could not imagine how she could live without her husband. (Dumas, 2000L 62)

Dantes faces a trial, an unofficial hearing without going through legal procedures. They tell Dantes that Dantes is arrested because Dantes has been proven to be an ally of the Napoleon party which is currently considered a banned organization. They further say that the arrival of Dantes to the island of Elba is related to the second wave of Napoleon's resistance to the authorities. Dantes cannot speak here; no one is on his side. He gives up, crying and no one hears or cares, a starting point of his ending.

\subsection{Inhuman Imprisonment.}

Dantes suffers a lot; he is tried in a court that without procedural standards and subsequently feels confident that he would never be released or in other words he tells himself that he would rot to death in jail. This is so because he is has been put in the category of political criminal and at that time, political crime is a serious crime and the person concerned could be sentenced to death.

He really feels betrayed, especially by the magistrate Villefort who says that Dantes would be released after the initial examination because Dantes has no indication of political 
criminal; but the reality is far different. He is sent to a terrible prison of that time, Chereu d'if. Nobody can get out of this prison. The prisoners sent here will only have names. They die in prison, not only because of mental and physical pains, but also they do not get proper treatment, coupled with a state of detention that is completely unfit for humans.

When Dantes is put into that horrible prison, Dantes keeps shouting, saying that he is innocent and that he is not an activist of Napoleon party. He keeps screaming like a mad person, but the guards ignore him as they think that Dantes has gone mad. For the guards there, prisoners who suddenly go insane are a common sight. Many prisoners who get into the prison get insane and die. And for the guards, all who enter the prison must be removed from the worl because those who are put there are dangerous prisoners. That is why they do not treat the prisoners humanely.

Owing to Dantes' increasingly violent behavior, screaming filled with anger, and berating all the guards and also the magistrate who has given false promises to him, the guards finally feel sure that Dantes has gone mad and Dantes is considered dangerous for them. Dantes is subsequently transferred to the dungeon, without good lighting and is very stuffy. This is where Dantes spends his days of uncertainty.

The guards also keep their distance from Dantes because they are afraid that something unexpected might happen. Dantes has been sentenced to be insane. He is placed alone in one cell and the condition of the cell is worse than the previous one. The room is indeed designed for special prisoners, deemed dangerous or those who have committed serious crimes. "I am innocent", this is a sentence that Dantes keeps sayiing and for the guards if a prisoner always says the same word or sentence repeatedly, then they immediately state that the prisoner is mad. This is the thing experienced by Dantes. Dantes always says that the magistrate would immediately release him, and this adds to the guards' confidence that Dantes has gone mad, even though Dantes is basically not mad. (Dumas, 2000: 160)

Dantes' state of mind worsens because of the condition of the cell. There are no windows at all; the sunlight could not penetrate the cell. Dantes has never been in such a place before so he feels very depressed and he thinks that he would rather die than have to experience such anguish. Dantes tries to pray but the situation does not change and this makes him even more desperate and intend to commit suicide.

Many times Dantes tries to pray. He speaks to God. He prays that God would immediately end his suffering and the condition remains unchanged. When he tries to commit suicide, his conscience says that the act of suicide is a betrayal to God. He goes on to say that he has no right to end his life because he is not a creator. He is really in a state of dilemma. Then he tells himself that he must continue to pray because prayer can ease the burden of his mind. (Dumas, 2000: 176)

Then Dantes tells God that if God could not eliminate his anguish, or at least alleviate his suffering, he asks God to end his life because he still assumes that God who has given life could also take his life. He is disappointed again because the changes he hope never come. He is increasingly depressed. He has lost everything; he has lost his freedom, something that is precious to humans. With such chaotic mind, Dantes then does not touch the food given to him. He thinks that hunger can end all his anguis. He tries again to commit suicide through starvation.

He throws away all the food given without the knowledge of the guards; thus he will not be disturbed by the guards because they naturally assume that the food they provide is still eaten. The food given to Dantes is also not suitable to eat. Dantes' condition worsens because he does not eat, and his mind also begins to be disturbed. He cannot think 
normally. Now he is convinced that he is indeed put in prison to die. Day and night, Dantes continues to pray that he could die soon. He is increasingly weak and frustrated. (Dumas, 2000: 195) This is a picture of the great anguish to be faced by Dantes in prison, a prison that is completely inhumane. The Chateu d'if prison is better called a place of torture, a place where anyone who enters will never come out alive.

\section{Conclusion}

Edmond Dantes, a protagonist of this novel, experiences a tremendous suffering. He suffer physically and mentally. His anguish begins when he is arrested on his wedding to a beautiful girl named Mercedes without going through proper procedures. He is accused of betraying the state through his espionage activities when he goes to Elba Island. Dantes rejects this accusation, but he is helpless because no one is on his side. He is completely helpless to face the indictment. Basically all these accusations are not true because Dantes is not a follower of Napoleon. He is betrayed by a group of people who are jealous and offended by him. He is also betrayed by the magistrate, Villefort, but not because of jealousy or offended feelings. Villefort feels uncomfortable with Dantes' departure to Elba to deliver a letter. The letter is addressed to his father, a follower of Napoleon and if this is revealed hif life is finished. So he must dump Dantes forever by sending him to the Chateu d'if prison.

The next Anguish experienced by Dantes is when he is in prison. He is treated inhumanely and the prison conditions also add to his misery. The prison is not suitable for habitation. His anguish gets bigger when he is put into a basement cell because he is considered mad and dangerous. At the peak of his suffering, he tries to end his life, but he is always faced with a dilemma. On one hand he could no longer stand the suffering and wants to end his life; but on the other hand his deepest inner voice says that he has no right to end his life because he is not a creator who can make life.

\section{References}

Cresswell, WJ. (2013). Mixed Method Research. Nebraska: University Press.

Dumas, Alexander. (2000). The Count of Monte Cristo. California: Penguin Classics.

Endaswara, Suwardi. (2003). Metodologi Kajian Sastra Epistemologi, Model, teori, dan Aplikasi. Yogyakarta: Pustaka Widyatama.

Faruk. (2013). Pengantar Sosiologi Sastra. Yogyakarta: Pustaka Pelajar

Gentil V and Gentil MLF. (2009). Why Anguish. Journal of Psychopharmacology. Vol. 25. No. 1. ResearchGate. Retrieved from https://www.researchgate.net/publication/ 40685171_Why_anguish

Herbert, Martin. (2010). Planning a Research Project. London: Cassel.

Hidayati, Hidayati. (2018). Local Wisdom of Kembar Mayang in Wedding Tradition of Jawa Ethnic. LANGUAGE LITERACY: Journal of Linguistics, Literature, and Language Teaching 2.1 (2018): 17-27. https://doi.org/10.30743/II.v2i1.552 